White Utopias 
The publisher and the University of California Press

Foundation gratefully acknowledge the generous support

of the Ahmanson Foundation Endowment Fund in Humanities. 


\section{White Utopias}

The Religious Exoticism of

Transformational Festivals

Amanda J. Lucia

甲

UNIVERSITY OF CALIFORNIA PRESS 
University of California Press

Oakland, California

(C) 2020 by Amanda J. Lucia

Cataloging-in-Publication Data is on file at the Library of Congress.

ISBN 978-0-520-37694-6 (cloth : alk. paper) ISBN 978-0-520-37695-3 (pbk. : alk. paper) ISBN 978-0-520-97633-7 (ebook)

Manufactured in the United States of America

$\begin{array}{llllllllll}29 & 28 & 27 & 26 & 25 & 24 & 23 & 22 & 21 & 20\end{array}$

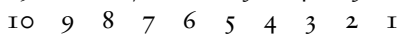


For my mother 

This has given me the greatest trouble and still does: to realize that what things are called is incomparably more important than what they are. The reputation, name, and appearance, the usual measure and weight of a thing, what it counts for-originally almost always wrong and arbitrary, thrown over things like a dress and altogether foreign to their nature and even to their skin-all this grows from generation unto generation, merely because people believe in it, until it gradually grows to be part of the thing and turns into its very body. What at first was appearance becomes in the end, almost invariably, the essence and is effective as such.

-Friedrich Nietzsche, The Gay Science 
